\title{
DESAIN DAN ANALISA SISTEM KONTROL RUANGAN DENGAN MENGGUNAKAN KEY TOOLS DAN PERINTAH SUARA
}

\section{Iwan Purwanto}

Fakultas Teknologi Industri, Universitas Trisakti

Email: iwan.purwanto@trisakti.ac.id

\begin{abstract}
Comfortable is a feature that is needed in a person's survival. Technological developments that continue to develop today, provide convenience for users, especially in creating security at home. Collaboration between technological developments and urgent needs provides added value for users to continue to improve and depend their needs on technological developments. It is hoped that renewable technology will be able to meet the needs of users from all sides. Responding to this, research will be carried out aimed at designing and knowing the conditions of product execution and will be adjusted to the minimum standard of renewable components. The measurement process is carried out at three scopes of signal capture with an emphasis on one sensor point and is carried out at three sensitive times, namely morning, afternoon and evening. The purpose of this research is to develop a remote home security system using the approach of space and time conditions in a certain condition. The research method proposed is qualitative research. The results show that it is very important that the consistency of space and time is stable and will result in a connectivity process that is coefficient in its operational processes, especially in supporting the process of remote connectivity in response to the sensitivity of instructions. The system's sensitivity to the conditions of users around the house and operators determines the typology of the people in the room as users. This typology can strengthen people's motivation to feel comfortable in a room with a signal stability object.
\end{abstract}

Keyword : sensors; qualitative; tripology.

\section{Abstrak}

Kenyamanan merupakan suatu untur yang sangat dibutuhkan dalam kelangsungan hidup seseorang. Perkembangan teknologi yang terus berkembang dewasa ini, menyediakan kenyamanan bagi pengguna terutama dalam menciptakan keamanan rumahnya.Kolaborasi antara perkembangan teknologi dan kebutuhan yang sifatnya urgent memberikan nilai tambah bagi user untuk terus meningkatkan serta menggantungkan kebutuhannya terhadap perkembangan teknologi. Teknologi terbarukan akan diharapkan akan dapat memenuhi kebutuhan user dari segala sisi. Menanggapi hal tersebut maka akan dilakukan penelitian yang bertujuan untuk melakukan rancang bangun dan mengetahui kondisi eksekusi produk dan akan disesuaikan dengan standar minimal komponen terbarukan. Proses pengukuran dilakukan pada tiga lingkup 
penangkapan sinyal dengan menitikberatkan pada satu titik sensor dan dilakukan pada tiga waktu sensitif waktu yaitu pagi, siang dan sore hari. Tujuan dari penelitian ini adalah mengembangkan sistem keamanan rumah denagn jarak jauh dengan menggunakan pendekatan kondisi ruang dan waktu dalam suatu kondisi. Metode penelitian yang diusulkan adalah penelitian kualitatif. Hasil penelitian dapat menunjukkan bahwa sangat penting konsistensi ruang dan waktu yang stabil akan menghasilkan proses konektifitas yang koefisien dalam proses operasionalnya, terutama mendukung proses konektifitas remote dalam merespon sensitivitas instruksi. Sistem sensitivitas kondisi pengguna di disekitar rumah dan operator menentukan tipologi orang di ruangan itu sebagai pengguna. Tipologi ini dapat memperkuat motivasi masyarakat untuk merasa nyaman berada di dalam ruangan dengan objek kestabilan sinyal.

Kata kunci: sensor; kualitatif; tripologi.

\section{Pendahuluan}

Kemajuan ilmu pengetahuan dan teknologi telah mendorong manusia untuk berusaha mengatasi segala permasalahan yang timbul di sekitarnya serta meringankan pekerjaan yang ada. Salah satu teknologi yang sedang berkembang saat ini adalah mikrokontroler. Mikrokontroler adalah keluarga mikroprosesor yaitu sebuah chip yang dapat melakukan pemrosesan data secara digital sesuai dengan perintah bahasa asembley yang diberikan. Dengan memanfaatkan mikrokoktroler ini dapat diciptakan suatu alat secerdas computer tetapi dengan biaya yang relative lebih murah dari pada computer

Keamanan merupakan salah satu komponen terpenting agar kegiatan operasional baik yang dilakukan di dalam ataupun di luar rumah dapat berjalan dengan baik dan benar, serta menciptakan kenyamanan bagi pemilik rumah. Dalam implementasinya sistem keamanan yang disesuaikan dengan kebutuhan dapat memicu terjadinya sistem otomasi. Logika kontrol berbasis aturan telah terbukti efisien untuk otomatisasi sistem naungan dan keamanan (Motamed, Bueno, Deschamps, Kuhn, \& Scartezzini, 2020). Sensor penangkapan objek dan pengolahan informasi berbaissi IoT merupkan fungsi subjek di dalamnya sistem operasional sistem (Parvin, Mushtaq, Kim, \& Choi, 2014). Melalui sistem tersebut proses pengeksekusian sistem dapat dilakukan dengan menggunakan pengontrolan/remote jarak jauh, hal tidak kalau pentingnya adalah bahwa instruksi dapat dipergunakan dengan menggunakan perintah suara (Baxter, Joseph, Osborne, \& Bedecarrats, 2014), dalam hal ini sistem keamanan dapat dilakukan dengan menggunakan pengontrolan jarak jauh. Pengembangan aplikasi digitalisasi dalam konteks rumah cerdasmenggunakan cakupan yang terbagi dalam beberapa komponen. Faktor yang memotivasi penelitian ini adalah meningkatnya popularitas perangkat pintar dalam desain serta pengembangan fakta bahwa perangkat ini telah digunakan dalam serangan ilegal dengan dampak yang besar (Do, Martini, \& Choo, 2018). Dalam suatu tulisan menyoroti pentingnya pengetahuan tentang sistem otomasi dan kesiapan keamanan di rumah pintar dan kota pintar untuk mempersiapkan diri menghadapi insiden keamanan di masa depan (Bajramovic, Waedt, Ciriello, \& Gupta, 2016). Rumah pintar dalam hal ini adalah perangkat kamar pintar yang berpotensi menjadi lebih kebal dalam penyidikan kriminal. (Do et al., 2018), Dalam kasus Informasi, ruang yang dapat dipindahkan dari konsep rumah pintar. dimana pendeteksian penangkapan sinyal dapat 
dilakukan dengan menggunakan sensor yang secara otomatis menstabilkan penangkapan sinyal di dalam ruangan (Bates, 2017).

Berdasarkan permasalahan yang dihadapi oleh industri produksi BJLS pada keterangan sebelumnya, maka kegiatan perencanaan produksi dalam hal memperkirakan jumlah produksi (kuantitas permintaan) dapat dilakukan berdasarkan data pemesanan produk yang didapatkan dari Sales Administration. Solusi ini dapat pula diselesaikan dengan bantuan perangkat lunak, yaitu berupa sistem informasi. Sistem informasi yang diusulkan adalah Sistem Informasi Perencanaan Produksi, yaitu untuk meramalkan jumlah produksi berdasarkan data pemesanan produk yang berupa data time series menggunakan metode peramalan yang bersesuaian. Metode peramalan time series yang digunakan untuk memperkirakan jumlah produksi dapat ditambahkan secara fleksibel pada sistem. Informasi berupa ramalan jumlah produksi dari hasil peramalan tersebut dapat digunakan untuk menyusun laporan perencanaan produksi bulanan.

Rumah pintar dalam hal ini adalah perangkat kamar pintar yang berpotensi menjadi lebih kebal dalam penyidikan kriminal. (Yeh, 2019), Dalam kasus Informasi, ruang yang dapat dipindahkan dari konsep rumah pintar. Dimana pendeteksian penangkapan sinyal dapat dilakukan dengan menggunakan sensor yang secara otomatis menstabilkan penangkapan sinyal di dalam ruangan.

\section{Metode Penelitian}

Dalam melaksanakan penelitian ini, penulis mengupasnya dengan menggunakan salah satu metode. Waterfall merupakan metode yang digunakan una mengembangkan aplikasi dari proses perencanaan hingga tahap ujicona dan penilaian kontent. Waterfall menjadi salah satu metode yang digunakan, karena menulis menilai komponen yang ada pada metode ini sapat merincikan tahapan kegiatan yang harus dan akan dilakukan. Proses analisis menyajikan alasan $5 \mathrm{~W} 1 \mathrm{H}$, guna pemenuhan alasan pengembangannya. Aktifitifias yang terjadi dalam metode Waterfall adalah sebagai berikut;

1. Requirement Analisis; Tahap ini merupakan tahap awal, dimana seorang pengembang wajib melakukan penganalisaan dengan beberapa pendekatan, diantaranya harus menjawab kunci pertanyaan 5 W 1 H. Keterpenuhan dalam menjawab pertanyaan yang mengandung unsur tersebut yang dikaitkan dengan menjawab peluang yang kemungkinan yang akan timbul dari sistem, akan meaksimalkan hasil akhir dari pengembangan.

2. System Design; aktifitas ini menjadi aktifitas kedua yang tidak kalah pentingnya untuk terus di laksanakan beradasarkan standar kontrol. Aktifitas yang dikakukan dalam tahapan ini adalah penentuan perangkat lunak (interface desigen, data base, hingga codding, tidak kalah pentingnya pengaturan perangkat keras (hardware) juga diatur dalam sub bab ini.

3. Implementation; aktifitas yang dilakukan dalam tahapan ini adalah melakukan ujicoba dari sistem yang sudah dirancang untuk dapat dipergunakan pada organisasi. Proses ujicoba merupakan tahapan awal dari tahap implementasi. Dalam implemetasi akan dilakukan sistem training dan updare aplikasi sesuai dengan temuan-temuan di lapangan.

4. Integration \& Testing; aktifitas yang dilakukan dalam tahapan ini adalah menyatukan unit0unit terkait yang memiliki korelasi dengan pengembangan sistem. Melakukan koordinasi yang berhubungan dengan bidang keilmuan 
terhadap aplikasi (sharing knowledge). Hal tersebut dilakukan guna memudahkan juka terjadi kendala dalam operasional sistem berjalannya.

5. Operation \& Maintenance; aktifitas ini merupakan akhir dari tahapan yang dilalui pada proses. Hal ini dilakukan guna melakukan perawatan dan perbaikan atas error yang terjadi pada sistem. Terdapat kesepakatan terhadap waktu tanggap hingga sistem dapat berjalan dengan baik (running well). Semua dapat dilakukan dan dikoordinasikan dengan baik dan benar sesuai standar operasional organisasi atau perusahaan.

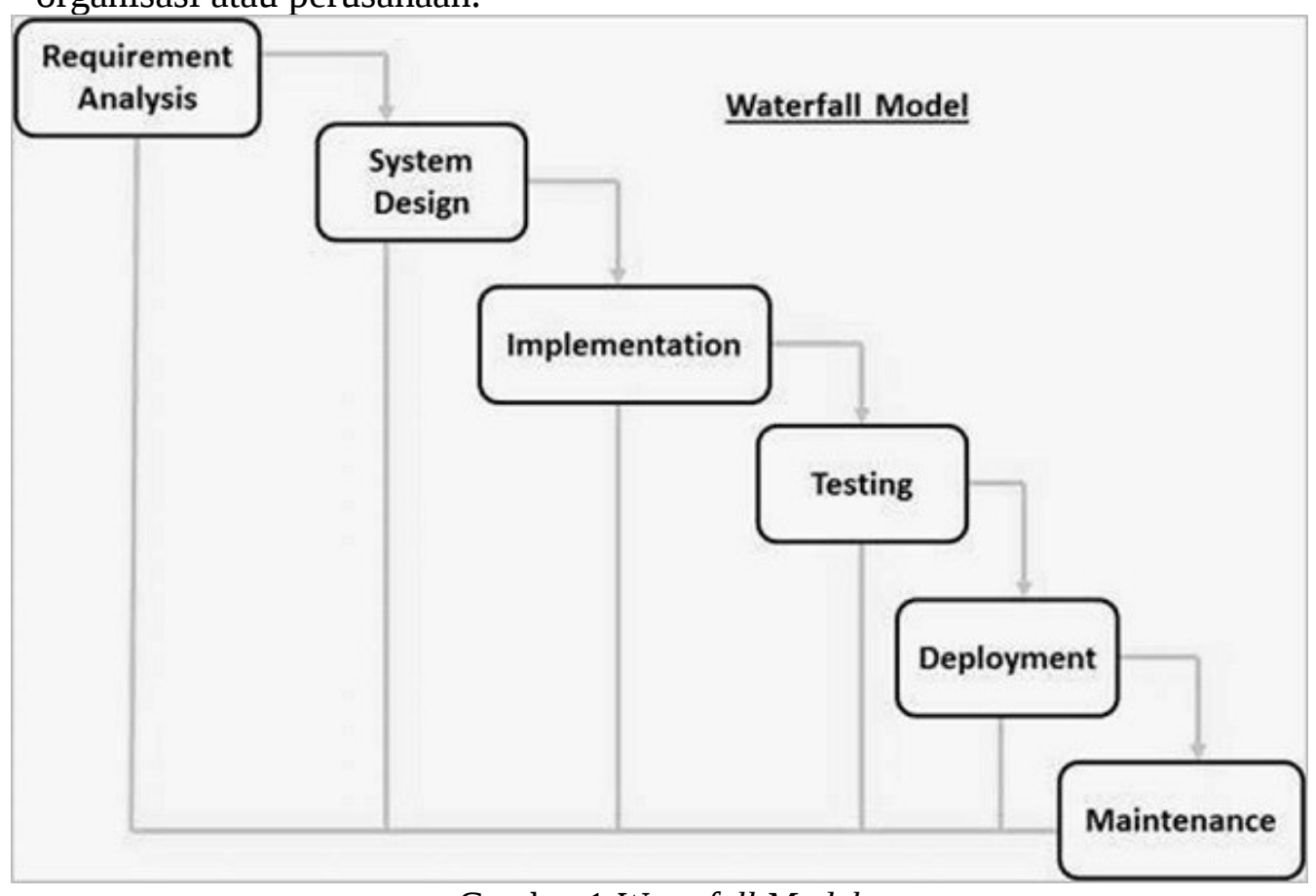

Gambar 1 Waterfall Model

\section{Hasil dan Pembahasan}

A. Requirement Analysis

Pengkondisian sistem keamanan dengan rumah menggunakan sistem remote yang dapat instruksikan dengan menggunakan perintah suara dapat di desain dengan menggunakan 2 pendekatan secara terseruktur.

Dua teknik pendekatan tersebut yaitu, dengan mengkondisikan perintah dengan menggunakan tombol/tools (MKP Tools) serta dengan menggunakan perintah suara yang dapat dikoneksikan dengan menggunakan google voice/voice note (MKP Node)

1. MKP Tools

MKP Tools merupakan serangkaian instruksi yang dapat disinkronisasikan dengan menggunakan perintah penekanan tombol, instruksi tersebut dapat mengikutsertakan beberapa komponen pengunaan objek. Katifitas yang dapat dikembangkan dalam instruksi ini mencakup beberapa komponen. Komponen yang telah dirancang dapat dianalogikan dengan beberapa perintah dan dapat diuraikan pada Tabel 1.

\section{Tabel 1 MPK Tools}

MKP ID Deskripsi


Desain dan Analisa Sistem Kontrol Ruangan dengan Menggunakan Key Tools dan Perintah Suara

\begin{tabular}{ll} 
MKP-Eksekusi-01 & Menghidupkan Lampu Dapur \\
\hline MKP-Eksekusi-02 & Mematikan Lampu Dapur \\
\hline MKP-Eksekusi-03 & Menghidupkan Lampu Ruang Tengah \\
\hline MKP-Eksekusi-04 & Mematikan Lampu Ruang Tengah \\
\hline MKP-Eksekusi-05 & Menghidupkan Lampu Ruang Tamu \\
\hline MKP-Eksekusi-06 & Mematikan Lampu Ruang Tamu \\
\hline MKP-Eksekusi-07 & Menghidupkan Lampu Teras \\
\hline MKP-Eksekusi-08 & Membuka Pagar \\
\hline MKP-Eksekusi-09 & Menutup Pagar \\
\hline MKP-Eksekusi-10 & Menghidupkan Lampu Taman \\
\hline MKP-Eksekusi-11 & Mematikan Lampu Taman \\
\hline \hline
\end{tabular}

2. MKP Node

MKP Node merupakan pengembangan instruksi dengan menggunakan perintah suara/voice noode. Perintah ini secara umum dapat diklasterkan sama seperti MPK Tools, namun instruksi yang dipergunakan dengan menggunakan perintah suara. Secara umum MKP Node dapat dideskripsikan pada Tabel 2 di bawah ini.

Tabel 2 MKP Node

\begin{tabular}{ll}
\hline MKP ID & Deskripsi \\
\hline MKP-Eksekusi-01 & Hidupkan Lampu Dapur \\
\hline MKP-Eksekusi-02 & Matikan Lampu Dapur \\
\hline MKP-Eksekusi-03 & Hidupkan Lampu Ruang Tengah \\
\hline MKP-Eksekusi-04 & Matikan Lampu Ruang Tengah \\
\hline MKP-Eksekusi-05 & Hidupkan Lampu Ruang Tamu \\
\hline MKP-Eksekusi-06 & Matikan Lampu Ruang Tamu \\
\hline MKP-Eksekusi-07 & Hidupkan Lampu Teras \\
\hline MKP-Eksekusi-08 & Buka Pagar \\
\hline MKP-Eksekusi-09 & Tutup Pagar \\
\hline MKP-Eksekusi-10 & Hidupkan Lampu Taman \\
\hline MKP-Eksekusi-11 & Matikan Lampu Taman \\
\hline \hline
\end{tabular}

Berdasarkan kebutuhan pengembangan sistem, analogi komponen di atas sapat dikembangkan dengan menggunakan diagram pengembangan sistem, seperti yang tertera pada gambar 2 di bawah ini: 


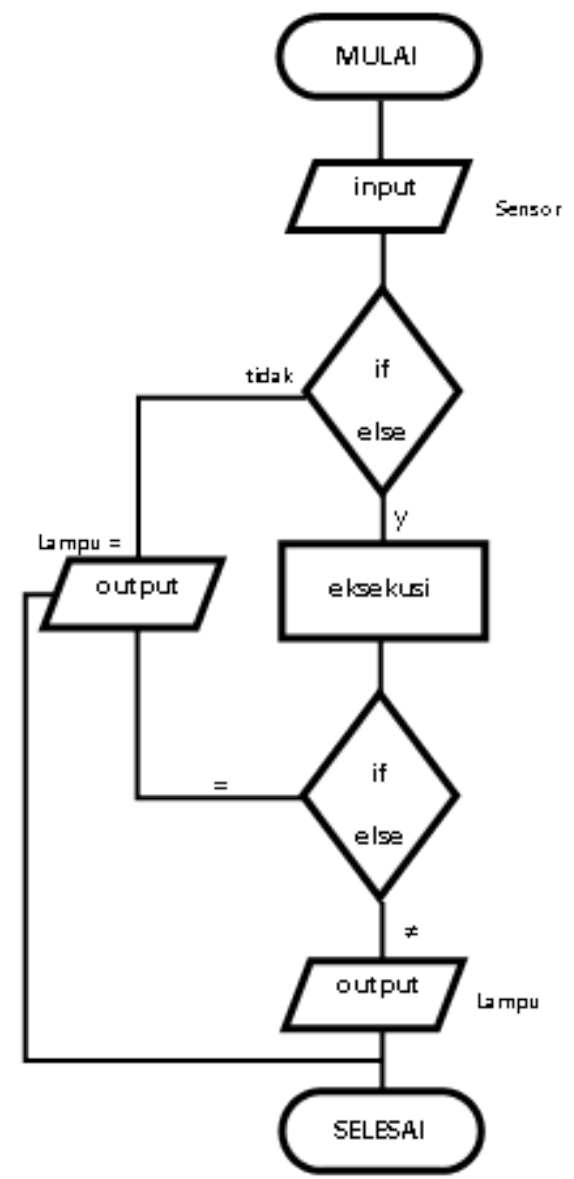

Gambar 2 Folwchart Sistem

B. System Design

Dalam mengembangkan konsep desain pencahaayaan ruangan otomatis ini, dibutuhkan dua indikator utama yaitu; perangkat keras (Hardware) dan desain prototype. Kedua komponen tersebut digabungkan dengan konsep kebutuhan nya masing-masing.

Secara umum proses kerja daoat digambarkan sebagai berikut:

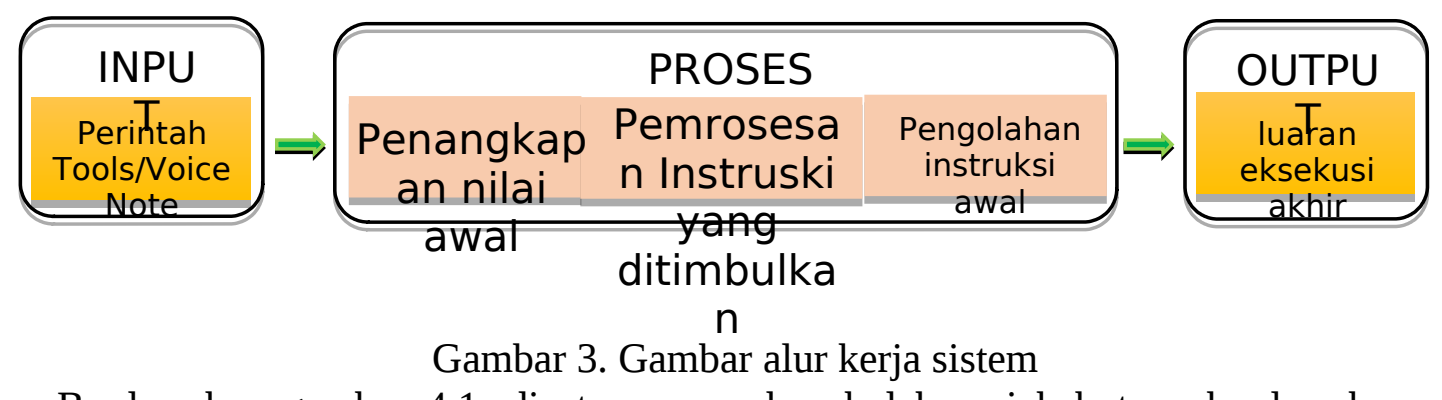

Berdasarkan gambar 4.1. di atas merupakan kolaborasi kebutuan berdasarkan perangkat lunak dan perangkat keras.

\section{Implementation and Unit Testing}

Proses ujicoba dilakukan dengan menggunakan dua kondisi guna memaksimalkan peroses uji coba. Kondisi pertma adalah langit buatan dan luar ruangan denga kondisi berawan dan langit cerah. Pengujian yang dilakukan 
dengan rekayasa penangkapan sinyal, memberikan nilai yang tepat dan memiliki akurasi yang tinggi. Pada sisi lain, guna menyajikan data yang tepat dan sesuai kebutuhan untuk dapat dilakukannya suatu pemrosesan dengan menggunakan penangkapan sinyal matahari langsung, perlu melakukan penggeseran pada derajat market, proses uji coba dengan menggunakan teknologi penangkapan sinyal matahari secara langsung juga sering dipergunakan. Berdasarkan hasil tangkap dan pengolahan data, bahwa simulasi yang dilakukan dengan menggunakan langit buatan dan penangkapan sinyal matahari secara langsung tidak memberikan perubahan yang begitu siknifikan. Langit buatan hemispherical akan menunjukan nilai pengukuran yang lebih akurat, sisi lain dari penggunaan langit ini terletak pada tingkat biaya yang lebih mahal dan beban dari lampu yang begitu besar. Sementara langit dengan cermin rectilinier menunjikan harga yang lebih murah dan berdasarkan skala beban tidak menunjukan ukuran yang berat. Guna mengembangkan proses analisa market di luar ruangan akan digunakan lampu sorot sebagai pengganti sinar matahari, terutama dengan menggunakan cermin rectilinier.

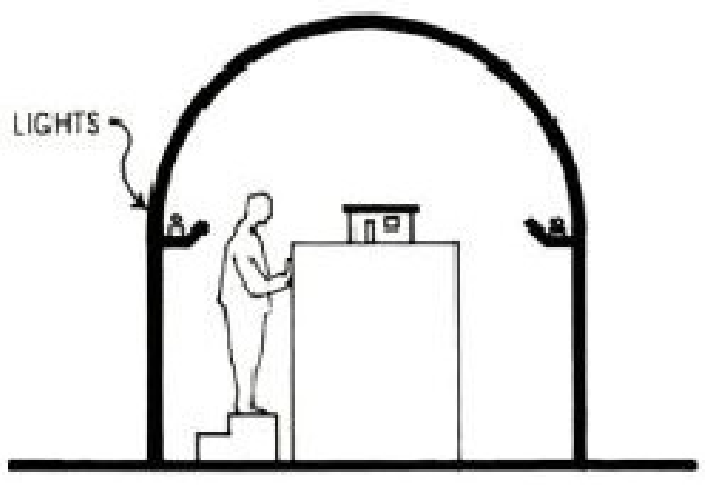

HEMISPHERICAL SKY

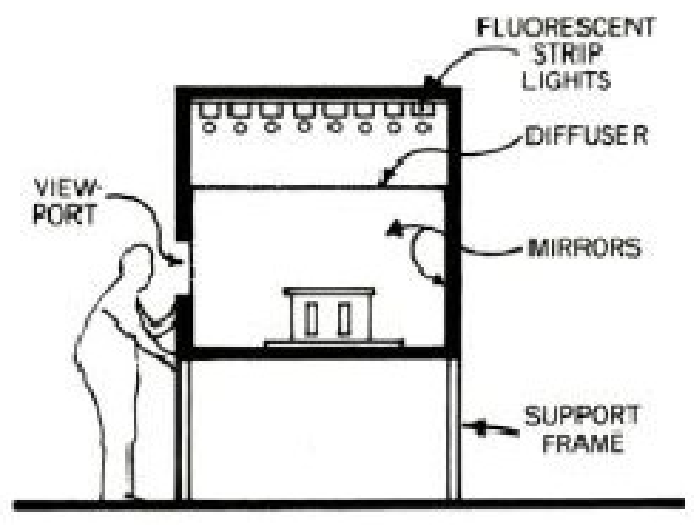

MIRROR SKY

Gambar 4. Konsep pengembangan objek

D. Integration and System Testing

Penggabungan antara sistem pembacaan node yang terekam berdasarkan konektifitas dan radiositas memiliki nilai koefisien yang mendekati sempurna, namun tuja sebaliknya dalam memberikan output terhadapt suatu daya tangkap. Dengan adanya kekuatan dan kelemahan tersebut keduanya aan saling melengkapi dan meminimalisir adanya bayers pada sub komponen. Hal tersebut dapat diketemukan pengembangan tehnik peradiasian, seperti halnya $4 D$ capturing, Scaning system, tehnik fotografi (bilting), proses photosintesa dan masih banyak lagi. Walaupun tehnik koefisien radiositas memiliki keterbatasan, namun langkah yang dilakukan oleh sistem pelacakan sinar cukup efektif untuk dilakukan, seperti yang terdapat pada gambar di bawah ini 


\begin{tabular}{|l|l}
\hline Ray tracing & Radiosity \\
\hline View-dependent & View-independent \\
\hline Handles specular behavior best & Handles diffuse behavior best \\
\hline Handles any geometry & Performs best with facetted shapes \\
\hline Can handle transparency & Performs best with opaque surfaces \\
\hline Does not compute the overall light distribution in the scene & Does compute the overall light distribution in the scene \\
\hline Has difficulties with indirect lighting & Indirect lighting is treated correctly \\
\hline
\end{tabular}

\section{Gambar 3. Nilai Koeefisien metode renderasi}

Dalam aktifitas pemetaan Poton ini, objek akan ditangkap berdasarkan bier sinar yang di pantulkan hingga mempengaruhi hasil akhir. Tehnik yang digunakan dalam proses pemetaan Photon ini adalah B-directionality ray tracking, serta mengembangkan salah satu metode forward atack ray traking dengan menggunakan metode tersebut di atas. Adapun aktifitas awal yang dilakukan adalah dengan mendistribusikan sebaran penangkapan sinyal dalam satu ruangan untuk kemudian dailakukan pengakumulasian terhadap B-directionality ray tracking dati titik akhir objek penghitungan. Metode ini mampu meminimalisit sebaran penangkapan sinyal gingga mendekati 8\%. Berdasarkan tingkat kompleksitas warna dapat disusutkan dengan menggunakan sautau pendekatan yang dianggap penting dan memiliki banyak kontribusi positif.

a. Tahap Uji coba Visualisasi

Proses penangkapan dan pengelolaan penangkapan sinyal yang dituangkan dalam bentuk pemvisualisasian menjadi suatu tantangan dengan menggunakan metode tersendiri dalam implementasinya. Proses yang dilakukan mampu menyajikan visualisasi data secara rugut dan tepat, sesuai dengan komponen nilai kepatuhan yang didapat berdasarkan standar dimensi tertentu. Prose uji coba ini melakukan penghitungan pada suatu transmisi, gerak tanpa sadar, dan penjabaran gerak material kasat serta kepekatan pada titik penangkapan sinyal suatu medan ruang. Hal tersebut menunjukan bahwa sifat suatu penangkapan sinyal yang beragam mampu mempersulit dalam proses pengkalkulasian tersebar dengan menggunakan suatu pendekatan berbasis objek.

Oleh karena itu, diperlukan suatu aktifitas kompresiasi yang bertujuan untuk memperkecil/menyederhanakan satuan daya tangkap dan juga proses. Beberpa program simulasi visual guna proses pancaran penangkapan sinyal yang sering digunakan diantaranya adalah audio Frecuency, LinghningFlox, Ximax Relux, Dellay SupraMix, RICOLIGHT, ADROMEDA, Light Transform, Mechine Sincering, Heiglight Transform, Digital visualizer dan masih banyak lagi program pendukung pengembang aplikasi yang mampu melakukan penghitungan terhadap proses kolaborasi sistem aplikasinya.

\section{b. Penilaian nilai akhir sebaran energy}

Pengembangan piranti lunak dewasa ini memberikan sinergi yang sagat baik dalam proses peredaman penangkapan sinyal yang diolah ke dalam tahap lanjut. Aktifitas tersebut menjadikan suatu peremajaan terhadap oefisien yang memiliki sinergi pada arau yang lebih melemahkan koefisien ruang. Koefisien yang dapat bertransformasi dengan faktor tersebut diantaranya; Indor \& Outror Radiology, Flexibility Transform, DELUX Luxuary, Incombent Transform, ICASO, Luminiare Syst, Audio Repidt, dan OUSTOPED. Dengan banyaknya jumlah komponen pengambangan 
kemampuan tersebut, menggambarkan bahwa deregulasi pada suatu tingkatan memiliki sebaran yang cukup beragam dan seimbang. Pergeseran tersebut menunjukan bahwa nilai suatu titik tidak dapat dipengaruni oleh adanya pergeseran ruang dan waktu.

\section{E. Operation \& Maintenance}

Dalam proses akumulasi koefisien nilai natural menggunakan beberapa satuan kegiatan memiliki tingkat kompleksitas yang cukup tinggi. Komponen faktor yang paling mendominasi adalah sumber penangkapan sinyal yang berasal dari alam. Sumber penangkapan sinyal ini dipengaruhi oleh faktor cuaca dan kondisi langit di sekitarnya. Berdasarkan data bangunan dan tampat belahan akan mampu menghasilkan luaran berdasarkan titik penangkapan sinyal dan nilai keterpengaruhannya terhadap satuan kualtias dan atu kuantitas yang masuk ke dalam ruangan untuk ditangkap dan diproses lebih lanjut.

Terdapat beberapa faktor yang mampu mempengaruhi muncilnya penilaian pada satuan tangkapan daya, diantaranya terdapat dalam tabel...... di bawah ini;

Tabel 3. Faktor Penentu Nilai Penangkapan Sinyal

\begin{tabular}{|c|c|c|c|}
\hline \multicolumn{3}{|c|}{ FAKTOR } & VARIAN \\
\hline \multirow{3}{*}{$\begin{array}{l}\text { Kondisi } \\
\text { Cuaca }\end{array}$} & \multicolumn{2}{|c|}{ Waktu penyinaran } & Bulan, tanggal, jam \\
\hline & \multicolumn{2}{|c|}{ Posisi geografis } & Letak lintang \\
\hline & \multicolumn{2}{|c|}{ Variasi komponen langit } & $\begin{array}{l}\text { Cerah Berawan } \\
\text { Mendung }\end{array}$ \\
\hline \multirow{11}{*}{$\begin{array}{l}\text { Data } \\
\text { Bangunan }\end{array}$} & \multicolumn{2}{|c|}{$\begin{array}{l}\text { Geometri bangunan } \\
\text { (ruang) }\end{array}$} & $\begin{array}{l}\text { Orientasi Bentuk } \\
\text { Dimensi bangunan }\end{array}$ \\
\hline & \multirow[t]{2}{*}{ Bukaan } & $\begin{array}{l}\text { Geometri } \\
\text { Bukaan }\end{array}$ & $\begin{array}{l}\text { Orientasi Posisi } \\
\text { Jumlah Bentuk } \\
\text { Dimensi bukaan } \\
\end{array}$ \\
\hline & & $\begin{array}{l}\text { Material } \\
\text { Bukaan }\end{array}$ & $\begin{array}{l}\text { Transparansi } \\
\text { Refleksi stur }\end{array}$ \\
\hline & \multirow[t]{2}{*}{$\begin{array}{l}\text { Faktor } \\
\text { refleksi }\end{array}$} & Refleksi Dalam & $\begin{array}{l}\text { Permukaan plafon } \\
\text { Permukaan dinding } \\
\text { Permukaan lantai }\end{array}$ \\
\hline & & Refleksi Luar & $\begin{array}{l}\text { Permukaan tapak } \\
\text { Permukaan bangunan sekitar }\end{array}$ \\
\hline & \multicolumn{2}{|c|}{ Kontribusi cahaya buatan } & $\begin{array}{l}\text { Ada/tidak } \\
\text { Kontrol cahaya (switching/dimming) }\end{array}$ \\
\hline & \multirow[b]{2}{*}{ Penghalang } & Internal & Tirai, kisi-kisi dalam, dll \\
\hline & & Eksternal & $\begin{array}{l}\text { Kusen, teritis/kanopi, kisi-kisi luar, sirip } \\
\text { penangkal sinar matahari, ketebalan dinding, } \\
\text { vegetasi, geometri } \\
\text { bangunan sekitar, pagar, dll }\end{array}$ \\
\hline & \multicolumn{2}{|c|}{ Perawatan } & Perawatan berkala / tidak \\
\hline & \multicolumn{2}{|c|}{ Polusi } & Pengaruh debu, asap, partikel lainnya \\
\hline & \multicolumn{2}{|l|}{ Isi ruang } & Perabot, Partisi, dll \\
\hline
\end{tabular}


Berdasarkan pendekatan di atas, menunjukan bahwa komponen yang tertera dalam melakukan pengakumulasian data mampu mengakomodir aktifitas penangkapan cahaya berdasarkan pemposisian sistem geografisnya. Pada sisi lain faktor pengisi ruangan pun belum dapat diidentifikasi secara maksimal, sehingga barier masih dapat ditemukan dalam beberapa titik. Pada metode kedua, sistem belum mempu menunjukan pemposisian serta aktifitas yang diorientasikan pada suatu bangunan atau pun sebaliknya yang dikaitkan dengan satuan ruang. Hal ini menunjukan bahwa dlaam suatu arsitektur akan menimbulkan satuan kendala atau permasalahan dalam sistem implementasinya.

Tabel 4. Perbandingan Metode Perhitungan Manual Dalam Perose Pemenuhan Kebutuhan Kondisi Penangkapan Sinyal Natural

\begin{tabular}{|c|c|c|c|c|}
\hline \multicolumn{3}{|c|}{ NILAI SEBARAN } & BRE/BRS & SNI \\
\hline \multirow{3}{*}{$\begin{array}{l}\text { Keadaan } \\
\text { Langit }\end{array}$} & \multicolumn{2}{|l|}{ Batasan } & 0 & 0 \\
\hline & \multicolumn{2}{|c|}{ Lokasi } & 0 & 0 \\
\hline & \multicolumn{2}{|c|}{ Sebaran tampak Atas Natural } & 1 & 0 \\
\hline \multirow{11}{*}{$\begin{array}{l}\text { Data } \\
\text { Bangunan }\end{array}$} & \multicolumn{2}{|c|}{ Tata letak objek } & 2 & 1 \\
\hline & \multirow[t]{2}{*}{ Tampak Dalam } & Paparan sudut & 2 & 1 \\
\hline & & Bahan ruang & 2 & 2 \\
\hline & \multirow[t]{2}{*}{ Pengayaan } & Bentuk dalam & 2 & 2 \\
\hline & & Bentuk luar & 2 & 2 \\
\hline & \multicolumn{2}{|c|}{ Desain Penangkapan sinyal } & 0 & 0 \\
\hline & \multirow[t]{2}{*}{ Bayer } & Dalam & 2 & 2 \\
\hline & & Luar & 2 & 2 \\
\hline & \multicolumn{2}{|l|}{ Perbaikan } & 2 & 0 \\
\hline & \multicolumn{2}{|l|}{ Sebaran Kasat } & 2 & 0 \\
\hline & \multicolumn{2}{|l|}{ Asesoris Internal } & 0 & 0 \\
\hline
\end{tabular}

Keterangan: 0 (nilai kosong), 1 (proses perhitugan dengan nilai varian kecil), 2 (proses perhitugan dengan nilai varian kecil varian cukup banyak), 3 (proses perhitugan dengan nilai varian melebihi kapasitas/bebas).

Proses perhitungan indeks penangkapan sinyal dengan mata pijar BRE, hanya mampu melakukan penghirungan pada nilai koefisien BRS yang sebenarnya, dan dapat diperhitungkan dengan menggunakan metode BRS berbasis tingkat kesilauan BGI.

Tabel 5. Komparasi Metode Koefisien aktifitas Manual dalam menganalisa Kondisi Penangkapan Sinyal secara natural

\begin{tabular}{|l|c|c|}
\hline \multirow{2}{*}{ Keterangan } & \multicolumn{2}{c|}{ Nilai } \\
& Ketercapaian \\
& $\begin{array}{c}\text { BRE/ } \\
\text { BRS }\end{array}$ & $\begin{array}{c}\text { SN } \\
\text { I }\end{array}$ \\
\hline DB & 1 & 1 \\
\hline DS & 3 & 3 \\
\hline UUD & 3 & 3 \\
\hline $\begin{array}{l}\text { Pancaran } \\
\text { Kepekatan }\end{array}$ & 3 & 3 \\
\hline Pancaran & 2 & 2 \\
\hline
\end{tabular}




\section{\begin{tabular}{|l|l|l|}
\hline Ketajaman & & \\
\hline
\end{tabular}}

Keterangan: 0 (proses perhitugan dengan tingkat kesulitan yang sangat rendah), 1 (proses perhitugan dengan tingkat kesulitan yang sedang), 2 (proses perhitugan dengan tingkat kesulitan yang sangat tinggi), 3 (tidak diperhitungkan).

Proses simulasi menggunakan market dapat di eksekusi dalam dua kondisi, hal ini memungkinkan karena ditinjau dari segi ukuran dan tingkat kerentanan, market yang memiliki sifat kecil dan fleksibel. Lokasi yang dimaksudkan adalah dalam ruangan dengan menggunakan bantuan penangkapan sinyal lampu, dan luar ruangan dengan menggunakan penangkapan sinyal alami. Kedua lokasi tersebut memiliki potensi penilaian yang berbeda-beda dalam proses perhitungannya. Berikut tabel hasil perhitungan terhadap pengujian martket pada kedua kondisi.

Tabel 6. Perbandingan Metode Simulasi Maket

\begin{tabular}{|c|c|c|c|c|}
\hline & \multicolumn{2}{|c|}{ INDIKATOR } & $\begin{array}{l}\text { DALAM } \\
\text { RUANG }\end{array}$ & $\begin{array}{c}\text { LUAR } \\
\text { RUANG }\end{array}$ \\
\hline \multirow{3}{*}{$\begin{array}{l}\text { Keadaan } \\
\text { Langit }\end{array}$} & \multicolumn{2}{|l|}{ Batasan } & 3 & 3 \\
\hline & \multicolumn{2}{|l|}{ Lokasi } & 3 & 3 \\
\hline & \multicolumn{2}{|c|}{ Sebaran tampak Atas Natural } & 3 & 3 \\
\hline \multirow{11}{*}{$\begin{array}{l}\text { Data } \\
\text { Bangunan }\end{array}$} & \multicolumn{2}{|c|}{ Tata letak objek } & 0 & 0 \\
\hline & \multirow{2}{*}{$\begin{array}{l}\text { Tampak } \\
\text { Dalam }\end{array}$} & \begin{tabular}{l|l} 
1 ata letak oDjek \\
Tamnak
\end{tabular} & 0 & 0 \\
\hline & & Bahan ruang & 0 & 0 \\
\hline & \multirow[t]{2}{*}{ Pengayaan } & Bentuk dalam & 0 & 0 \\
\hline & & Bentuk luar & 0 & 0 \\
\hline & \multicolumn{2}{|c|}{ Desain Penangkapan sinyal } & 3 & 3 \\
\hline & \multirow[t]{2}{*}{ Bayer } & Dalam & 0 & 0 \\
\hline & & Luar & 0 & 0 \\
\hline & \multicolumn{2}{|c|}{ Perbaikan } & 3 & 3 \\
\hline & \multicolumn{2}{|c|}{ Sebaran Kasat } & 3 & 3 \\
\hline & \multicolumn{2}{|c|}{ Asesoris Internal } & 3 & 3 \\
\hline
\end{tabular}

Keterangan: 0 (diperhitungkan, varian bebas), 1 (diperhitungkan, varian sebaran cukup ), 2 (diperhitungkan, varian sebaran minim), 3 (tidak diperhitungkan).

Dalam proses pengukuran pemposisian langit buatan memiliki kelebihan yang terukur dalam proses pengukurannya. Hal ini dikarenakan pengukuran cahaya yang terjadi di ruangan mengeluarkan cahaya yang kuat saay pengukuran. Kuatnya nilai penangkapan sinyal diakibatkan sabaran penangkapan sinyal terjadi secara merata. Denagn dilakukannya penambahan penangkapan sinyal dengan menggunakan lampu tembak memperkuat indikator penangkapan sinyal yang dapat mewakili efek penangkapan sinyal dari sinar matahari. Hal yang tidak kalah menariknya adalah bahwasanya retjadi eprgeseran penilaian tipis jika dilakukan perpindahan berdasarkan satuan titik ekuifalensi.

\section{Kesimpulan}

Sistem pengamanan rumah dengan menggunakan sistem remot dengan menggunakan tools dan perintah suara akan sangat membantu sistem keamanan rumah. Sistem pengontorlan keamanan rumah yang maksimal akan memberikan kenyamanan bagi pemilik saat akan meninggalkan rumah. Di sisi lain sistem penyerapan dan hemat energi pun dapat di minimalisir, karena sistem dapat Jurnal Indonesia Sosial Teknologi, Vol. 2, No. 1, Januari 2021 
Iwan Purwanto

mematikan lampu dengan menggunakan sistem remot.

Pada sisi lain, sistem penilaian pengukuran kapasitas aplikasi penerangan yang dilakukan menunjukan bahwa sistem terdistribusi dengan menggunakan sistem otomatis akan lebih menguatkan nilai kerja aplikasi. Hal tersebut dikarenakan tingkat sensitifitas snsor dalam mengakumulasikan nilai, lebih memiliki kompleksitas yang dinggi dan nilai akurasi dengan standar nilai sangat baik. 


\section{Bibliography}

Bajramovic, Edita, Waedt, Karl, Ciriello, Antonio, \& Gupta, Deeksha. (2016). Forensic readiness of smart buildings: Preconditions for subsequent cybersecurity tests. 2016 IEEE International Smart Cities Conference (ISC2), 1-6. IEEE.

Bates, Andrew. (2017). Journalism and Truth: The implications of a Foucauldian approach to knowledge and the subject on the role of the journalist in 2016 Britain. University of Gloucestershire.

Baxter, M., Joseph, N., Osborne, V. R., \& Bedecarrats, G. Y. (2014). Red light is necessary to activate the reproductive axis in chickens independently of the retina of the eye. Poultry Science, 93(5), 1289-1297.

Do, Quang, Martini, Ben, \& Choo, Kim Kwang Raymond. (2018). Cyber-physical systems information gathering: A smart home case study. Computer Networks, 138, 1-12.

Motamed, Ali, Bueno, Bruno, Deschamps, Laurent, Kuhn, Tilmann E., \& Scartezzini, Jean Louis. (2020). Self-commissioning glare-based control system for integrated venetian blind and electric lighting. Building and Environment, 171, 106642.

Parvin, R., Mushtaq, M. M. H., Kim, M. J., \& Choi, H. C. (2014). Light emitting diode (LED) as a source of monochromatic light: a novel lighting approach for behaviour, physiology and welfare of poultry. World's Poultry Science Journal, 70(3), 543-556.

Yeh, Shih Chuan. (2019). High performance natural lighting system combined with SPSC. Renewable Energy, 143, 226-232.

I. Zeifman, D. Bekerman, and B. Herzberg (2016). Breaking down mirai: an IoT DDoS botnet analysis, Accessed 9th; https://www.incapsula.com/ blog/malware-analysismirai-ddos-botnet.html.

Level 3 Threat Research Labs (2016). Attack of things!, Accessed 9th; http://blog.level3.com/ security/attack- of- things/.

E. Bajramovic , K. Waedt , A. Ciriello , D. Gupta (2016), Forensic readiness of smart buildings: preconditions for subsequent cybersecurity tests, in: Proceedings of the IEEE International Smart Cities Conference, 2016, pp. 1-6..

State v James Andrew Bates, Case ID: 04CR-16-370.

T. Nam , T.A. Pardo (2011), Conceptualizing smart city with dimensions of 
Iwan Purwanto

technology, people, and institutions, in: Proceedings of the 12th Annual International Dig- ital Government Research Conference: Digital Government Innovation in Chal- lenging Times, College Park, Maryland, USA, , pp. 282-291.

S. Chaiyapinunt, N. Khamporn (2014), Heat transmission through a glass window with a curved Venetian blind installed, Sol. Energy 110 () 71-82.

Lenchner Norbert (2017), Heating, Cooling, Lighting. New Jersey: John, Wely \& Son.

Commonwealth v. Risley (2016), criminal docket: CP-36-CR-0 0 02937-2015.

R v Baden-Clay, QSC 156, 2014 p. 1 (Supreme Court of Queensland). 